AKSARA Jurnal Bahasa dan Sastra

Vol. 20, No. 1, Hal. 1 - 9, April 2019

http://jurnal.fkip.unila.ac.id/index.php/aksara

\title{
Analisis Kebutuhan Materi Audio berdasarkan Kurikulum Pembelajaran Bahasa Indonesia Kelas XII Australia
}

\author{
Meita Enjayani \\ Universitas Sanata Dharma \\ enjayanimeita@gmail.com
}

\begin{abstract}
Indonesian Language for Foreign Speaker (BIPA) has shown good development every year. One country with high number of Indonesian Language learners is Australia. As a close neighbour of Indonesia, Australia has special attention to Indonesian language. Some schools in Australia even require students to learn Indonesian language. Based on the initial interview with one of the teacher, it reveals that Indonesian learning materials for class XII in form of audio is still needed. Therefore, researchers are interested in conducting needs analysis to get an overview of the learning material needed as a foundation to conduct research and development. This research is the initial stage of development research. This is need analysis process to gather relevant information on the research. Need analysis is done through interviews with teachers and document analysis of class XII Indonesian learning curriculum. The results of this study shows that there is a great need of developing authentic audio material which is related to the topics such as texts and genres, media and entertainment, globalization and the media, youth issues, social issues, and Australian/Indonesian relations.
\end{abstract}

Abstrak. Program Bahasa Indonesia bagi Penutur Asing (BIPA) menjadi suatu hal yang menarik dan diminati dari tahun ke tahun. Salah satu negara dengan jumlah peminat Bahasa Indonesia tinggi adalah negara Australia. Sebagai tetangga dekat Indonesia, Australia memiliki perhatian khusus terhadap bahasa Indonesia. Beberapa sekolah di Australia bahkan mewajibkan siswanya untuk belajar Bahasa Indonesia. Berdasarkan wawancara awal dengan salah satu pengajar, disebutkan bahwa pembelajaran bahasa Indonesia bagi kelas XII dalam bentuk audio masih dibutuhkan. Oleh karena itu, peneliti tertarik untuk melakukan analisis kebutuhan untuk mendapatkan gambaran kebutuhan materi pembelajaran sebagai dasar untuk melakukan penelitian pengembangan. Penelitian ini merupakan tahap awal dari penelitian pengembangan, yaitu analisis kebutuhan untuk mengumpulkan informasi yang relevan dengan penelitian. Analisis kebutuhan dilakukan melalui wawancara dengan pengajar serta analisis dokumen yang berupa kurikulum pembelajaran kelas XII. Hasil penelitian ini menyatakan adanya kebutuhan pengembangan materi audio yang autentik yang berkaitan dengan topik mengenai teks dan genre, media dan hiburan, globalisasi dan media, masalah remaja, isu-isu sosial, dan hubungan Australia / Indonesia.

Kata kunci: Analisis Kebutuhan, Materi Audio, Kurikulum Pembelajaran Bahasa Indonesia di Australia 


\section{PENDAHULUAN}

Bidang pengajaran bahasa kedua terus berkembang sebagai akibat dari berbagai faktor yang terkait dengan globalisasi dan internasionalisasi masyarakat. Menguasai bahasa selain bahasa ibu memberikan nilai yang lebih bagi seseorang untuk mendapatkan peluang dalam pendidikan maupun lapangan kerja. Bahasa Indonesia juga menjadi salah satu pilihan bahasa kedua yang dipelajari oleh penutur asing. Bahasa Indonesia yang dipelajari oleh orang asing ini dikenal dengan istilah BIPA (Bahasa Indonesia bagi Penutur Asing).

Program BIPA menjadi suatu hal yang menarik dan diminati dari tahun ke tahun. Menurut tulisan dalam laman Badan Pengembangan dan Pembinaan Bahasa (2012), ada setidaknya 45 lembaga yang telah mengajarkan bahasa Indonesia bagi penutur asing (BIPA), baik di perguruan tinggi maupun di lembaga-lembaga kursus di dalam negeri. Sementara itu, di luar negeri, pengajaran BIPA dilakukan oleh sekitar 36 negara dengan jumlah lembaga setidaknya 130 buah, yang terdiri atas perguruan tinggi, pusat-pusat kebudayaan asing, KBRI, dan lembaga-lembaga kursus. Selain itu, didirikan juga lembaga pemerintah yang khusus menangani perkembangan program BIPA seperti Pusat Pengembangan Strategi dan Diplomasi Kebahasaan (PPSDK) yang merupakan bagian dari Badan Pengembangan dan Pembinaan Bahasa. Lebih dari itu, melalui peraturan menteri tenaga kerja dan transmigrasi nomor 12 tahun 2013 mengenai syarat kemampuan berkomunikasi bagi tenaga kerja asing, program pengajaran BIPA semakin berkembang.

Salah satu negara dengan jumlah peminat Bahasa Indonesia tinggi adalah negara Australia. Sebagai tetangga dekat Indonesia, Australia memiliki perhatian khusus terhadap bahasa Indonesia. Beberapa sekolah di Australia bahkan mewajibkan siswanya untuk belajar Bahasa Indonesia. Slaughter (2007) menyebutkan bahwa pada tahun 2003, bahasa Indonesia ditawarkan oleh ratusan sekolah di semua negara bagian dan teritori di Australia, dengan jumlah 1.898 siswa kelas XII yang belajar bahasa Indonesia dimana 161 diantaranya mengambil bahasa Indonesia sebagai bahasa pertama. Kohler dan Mahnken (2010) menyebutkan bahwa berdasarkan hasil otoritas penilaian dan kurikulum tahun 2009, tercatat sebanyak 1,167 siswa kelas XII terdaftar dalam kelas Bahasa Indonesia.

Berdasarkan wawancara awal dengan salah satu pengajar, disebutkan bahwa materi pembelajaran dalam bentuk audio masih dibutuhkan. Oleh karena itu, peneliti tertarik untuk melakukan analisis kebutuhan untuk mendapatkan gambaran kebutuhan materi pembelajaran sebagai dasar untuk melakukan penelitian pengembangan. 
AKSARA Jurnal Bahasa dan Sastra

Vol. 20, No. 1, Hal. 1 - 9, April 2019

http://jurnal.fkip.unila.ac.id/index.php/aksara

\section{KAJIAN TEORI}

\section{Pembelajaran BIPA}

Pembelajaran bahasa Indonesia oleh penutur asing merupakan pembelajaran bahasa kedua atau pembelajaran bahasa asing. Dalam pembelajaran bahasa kedua, terjadi proses pemerolehan dan pembelajaran bahasa. Proses pemerolehan dikenal sebagai proses alamiah dalam konteks informal sedangkan proses pembelajaran didefinisikan sebagai proses formal secara sadar untuk mempelajari kaidah kebahasaan. Menurut Krashen (1981), proses pemerolehan bahasa kedua dapat terjadi secara attitude dan juga aptitude. Attitude adalah pemerolehan bahasa secara tidak disadari dimana pembelajar dapat memperoleh dan memahami bahasa kedua dengan metode mendengarkan dan membaca. Aptitude adalah pemerolehan bahasa kedua secara sadar dengan mempelajari dan memperhatikan bentuk, memahami aturan, dan secara umum memahami proses bahasa itu sendiri.

Kesulitan pembelajar dalam proses pemerolehan bahasa kedua adalah karena adanya gap dan perbedaan antara bahasa pertama dan bahasa target atau dalam konteks ini adalah bahasa Indonesia. Suyitno (2017) mengungkapkan bahwa pada tahap awal pembelajaran BIPA, pembelajar masih sangat dipengaruhi oleh bahasa, budaya, dan gaya belajar pertama yang mereka pelajari. Penguasaan dan pemerolehan bahasa yang dipelajari sangat dipengaruhi oleh bahasa pertama. Hal terjadi karena kurangnya pengetahuan tentang bahasa target oleh pembelajar asing.

\section{Keterampilan Menyimak}

Menyimak memiliki peran penting dalam kehidupan sehari-hari untuk mempertahankan komunikasi yang efektif. Pentingnya keterampilan menyimak mulai mengambil tempat di program pengajaran bahasa selain berbicara, membaca dan menulis. Dengan munculnya pengajaran bahasa komunikatif pada akhir 1970-an, perhatian akan keterampilan menyimak dalam pembelajaran bahasa kedua semakin meningkat (Yildirim, 2016).

Menyimak memiliki tempat yang penting dalam pembelajaran karena keterampilan ini memiliki kontribusi utama untuk keahlian bahasa. Menyimak dapat menumbuhkan kesadaran akan bahasa sebagaimana adanya keterampilan reseptif yang pertama kali berkembang dalam diri manusia. Belajar mendengarkan target bahasa tentunya dapat meningkatkan kemampuan bahasa. Suara, irama, intonasi, dan penekanan dari suatu bahasa hanya bisa diadaptasi secara sempurna melalui kegiatan menyimak (Renukadevi, 2014). Selanjutnya, Rost (1994) juga menjelaskan pentingnya menyimak dalam kelas bahasa sebagai berikut: 
a. Keterampilan menyimak sangat penting di kelas bahasa karena dapat memberikan input untuk pelajar. Tanpa memahami adanya input pada tingkat yang tepat, pembelajaran tidak dapat dimulai dengan tepat.

b. Bahasa lisan menyediakan sarana interaksi untuk pembelajar karena pembelajar harus berinteraksi untuk mencapai pemahaman. Interaksi dengan penutur asli bahasa menjadi sangat penting. Kegagalan siswa untuk memahami bahasa yang didengar dapat menjadi suatu dorongan, bukan hambatan, untuk interaksi dan pembelajar.

c. Bahasa lisan yang autentik memberikan tantangan bagi pelajar untuk memahami bahasa sebagaimana penutur asli benar-benar menggunakannya.

d. Latihan menyimak memberikan sarana bagi pengajar untuk mengajarkan peserta didik mengenai bentuk baru dalam bentuk kosakata, tata bahasa, maupun pola interaksi baru. (Yildirim, 2016).

\section{Materi Autentik Audio}

Materi autentik merupakan materi cetak yang digunakan di ruang kelas dengan cara yang sama ketika digunakan dalam kehidupan nyata (Jacobson, dkk., 2003). Selain itu, materi autentik juga didefinisikan sebagai suatu perluasan dari bahasa yang nyata, yang diproduksi oleh penutur atau penulis untuk mengungkapkan pesan tertentu (Gilmore, 2007). Dengan demikian, dapat disimpulkan bahwa materi autentik merupakan sumber pembelajaran yang didapatkan dari komunikasi nyata dalam kehidupan sehari-hari.

Sumber pembelajaran autentik dapat diperoleh dari bahan cetak dan juga audio. Bahan cetak dapat diperoleh dari koran, majalah, brosur, novel, cerita pendek, iklan, dan buku. Materi audio-visual dapat diperoleh dari program TV dan radio, film, lagu, dan bahkan film dari YouTube. Berbagai macam sumber pembelajaran autentik tersebut dapat dimanfaatkan pengajar untuk memberikan pembelajaran bahasa yang nyata (Belaid, 2015; Adam dkk., 2010)

Melalui materi autentik, pembelajar memahami materi dengan bahasa nyata yang dituturkan oleh pembicara dalam situasi nyata. Dalam hal ini, fokus ada pada bahasa untuk menyampaikan pesan sedangkan fitur bahasa seperti format, gaya bahasa dan konteks sering digunakan untuk membantu komunikasi. Materi autentik dapat menjadi sebuah jembatan bagi pembelajar untuk mengenal komunikasi dalam dunia nyata, seperti halnya yang dituturkan oleh penutur asli. Lebih lanjut lagi, melalui penggunaan materi autentik, pembelajar akan telatih dan menjadi lebih percaya diri untuk berkomunikasi dalam situasi nyata. Pembelajar juga akan lebih 
terbiasa untuk menggunakan bahasa yang natural karena mereka belajar dari bahasa yang ada pada masyarakat (Adam, dkk., 2010).

\section{HASIL DAN PEMBAHASAN}

\section{Analisis Kebutuhan Materi Pembelajaran Audio Berdasarkan Wawancara}

Proses analisis kebutuhan dalam penelitian ini dilakukan melalui wawancara yang dilakukan dengan pengajar bahasa Indonesia di Australia. Berdasarkan hasil wawancara, diperoleh deskripsi mengenai materi audio yang dibutuhkan dalam pembelajaran bahasa Indonesia. Materi audio yang diharapkan berupa materi yang autentik sehingga pembelajar dapat terlatih untuk mendengarkan pelafalan oleh penutur asli Indonesia. Hal ini akan membantu melatih siswa dalam memahami teks lisan.

Adam, dkk. (2010) mengungkapkan bahwa materi audio-video adalah aspek yang sangat penting dalam mengajar bahasa asing karena pembelajar dapat memperoleh pelafalan yang alami serta pembelajar dapat meningkatkan keterampilan mendengarkan. Dalam hal ini, materi pembelajaran dalam bentuk audio dibutuhkan di sekolah Australia Barat karena kebanyakan guru bahasa Indonesia bukan penutur asli bahasa Indonesia. Dengan adanya materi pembelajaran bahasa dalam bentuk audio, pembelajar dapat terlatih untuk mendengarkan penggunaan bahasa Indonesia dalam komunikasi nyata penutur asli bahasa Indonesia. Selain itu, siswa yang memiliki keterbatasan dalam keterampilan membaca dapat belajar dari audio dengan mendengarkan dan mengulanginya sesuai kebutuhan. Dengan adanya audio, pembelajar dapat mendengarkan pengucapan seorang penutur asli dan sekaligus dapat menirukan dan membandingkan pengucapan yang dihasilkan sendiri (Smaldino, 2011).

Materi yang berupa audio ditujukan untuk melatih kemampuan reseptif pembelajar, yaitu keterampilan menyimak. Proses menyimak dimulai dengan adanya suatu kesadaran dan perhatian akan suara, pola kalimat, diikuti dengan identifikasi dan pengenalan, dan diakhiri dengan pemahaman (Smaldino, 2011). Hal ini juga yang menjadi pembeda antara aktivitas mendengarkan dan aktivitas menyimak. Lebih lanjut lagi, beberapa teknik untuk dapat meningkatkan keterampilan menyimak dapat diuraikan sebagai berikut:

1. Menyampaikan tujuan pembelajaran serta mengajukan beberapa pertanyaan sebelum memulai aktivitas menyimak

2. Meminta siswa untuk mencari gagasan pokok dan kemudian mencatatnya

3. Menggunakan konteks dalam menyimak untuk membantu siswa mengartikan suatu kata yang belum diketahui artinya 
4. Menganalisa struktur materi simakan serta menemukan ide utama dan sub ide

5. Mengidentifikasi hal-hal yang sesuai dan tidak sesuai (Smaldino, 2011)

\section{Materi Pembelajaran Audio Berdasarkan Kurikulum kelas XII}

Pembelajaran bahasa Indonesia bagi siswa kelas XII merupakan salah satu pilihan pembelajaran selain bahasa Inggris atau yang lebih dikenal dengan istilah LOTE (Language Other Than English). Silabus untuk kelas XII merupakan kelanjutan dari silabus pada tingkat kelas sebelumnya, yaitu kelas XI. Kelas XI memuat dua unit yaitu unit 1 dan unit 2, sedangkan kelas XII mencakup dua unit selanjutnya yaitu unit 3 dan 4. Kedua unit tersebut dapat diuraikan secara mendetail sebagai berikut:

\section{Unit 3}

Unit ini berfokus pada ragam wacana. Tiga topik utama dalam unit ini memuat teks dan genre, media dan hiburan, dan globalisasi dan media. Topik mengenai teks menuntun siswa untuk melakukan analisis kritis dan menanggapi teks melalui refleksi dan berbagi pendapat untuk mengembangkan perspektif pribadi. Dalam topik media dan hiburan, siswa mengeksplorasi film, televisi, media cetak dan online Indonesia serta pengaruhnya terhadap kehidupan sehari-hari di Indonesia. Topik globalisasi dan media mengarahkan siswa untuk dapat melihat pengaruh globalisasi pada media terhadap persepsi dan identitas Indonesia. Dengan adanya topik-topik tersebut, siswa dapat memperluas dan menyempurnakan keterampilan komunikasi mereka dalam bahasa Indonesia serta memperoleh pemahaman yang lebih luas dan lebih mendalam tentang bahasa dan budaya.

\section{Unit 4}

Unit ini berfokus pada isu hangat untuk mengeksplorasi masalah terkini. Tiga topik utama dalam unit ini memuat masalah remaja, isu-isu sosial, dan hubungan Australia / Indonesia. Topik mengenai isu remaja meliputi isu-isu dalam kehidupan sehari-hari siswa, seperti keluarga, sekolah, kehidupan sosial dan kesehatan. Topik mengenai isu sosial berhubungan dengan pendidikan, kesehatan, kemiskinan dan lingkungan dan bagaimana dampaknya terhadap kehidupan sehari-hari di komunitas Indonesia. Selanjutnya, topik mengenai hubungan Australia/Indonesia mencakup peristiwa ekonomi, politik, dan isu terkini yang dapat mempengaruhi hubungan Australia / Indonesia, serta melihat peluang belajar dan karir. Dengan adanya topik-topik tersebut, siswa dapat memperluas dan menyempurnakan keterampilan komunikasi mereka dalam bahasa Indonesia dan memperoleh pemahaman yang lebih luas dan lebih mendalam tentang bahasa dan budaya. 
Konten pembelajaran bahasa Indonesia bagi kelas X11 Australia Barat memuat lima area yaitu konteks pembelajaran dan topik, jenis teks, fitur linguistik, pemahaman antar budaya serta pembelajaran bahasa dan trategi komunikasi. Konten ini harus disajikan secara utuh dan tidak terpisah. Konten area yang diajarkan saling berhubungan dan bergantung satu sama lain. Masing-masing konten area tersebut dapat dijabarkan secara lebih lanjut dalam uraian berikut:

\section{Konteks pembelajaran dan topik}

Konteks pembelajaran antara lain individu, komunitas penutur bahasa Indonesia, perubahan dunia. Setiap konteks pembelajaran memiliki serangkaian topik yang mendorong terjadinya komunikasi yang bermakna dan memungkinkan siswa untuk memperluas pemahaman mereka tentang bahasa dan budaya Indonesia. Penempatan topik di bawah satu atau lebih dari tiga konteks pembelajaran dimaksudkan untuk memberikan perspektif tertentu.

\section{Jenis teks}

Jenis teks dapat dikategorikan ke dalam teks cetak, lisan, visual atau audiovisual, dan dapat diidentifikasi dalam hal tujuan, pemirsa, dan fitur bahasa. Dalam mempelajari suatu bahasa, penting untuk terlibat dan menghasilkan berbagai jenis teks. Jenis teks dan konvensi tekstual yang bervariasi di berbagai bahasa dan budaya dapat memberikan informasi tentang masyarakat dan budaya di mana teks tersebut diproduksi. Selain itu, fitur, pola dan aturan teks, yang ditentukan oleh jenis teks, konteks, audiens dan tujuan teks juga menunjukkan cara untuk berpartisipasi dalam komunikasi, seperti cara memulai percakapan, menyampaikan permintaan, mengungkapkan ketidaksetujuan, dan juga memberikan merespons. Siswa akan menyadari karakteristik dalam suatu teks yang berbeda. Dalam hal ini, siswa didorong untuk mendengarkan, membaca dan melihat berbagai teks, dan diberikan kesempatan untuk mempraktikkannya.

\section{Fitur linguistik}

Fitur linguistik adalah elemen khusus yang diperlukan dalam komunikasi. Mempelajari fitur linguistik memungkinkan pengembangan pengetahuan, keterampilan, dan pemahaman yang relevan dengan kosakata, tata bahasa, dan sistem penulisan dan bunyi dalam bahasa Indonesia. 
AKSARA Jurnal Bahasa dan Sastra

Vol. 20, No. 1, Hal. 1 - 9, April 2019

http://jurnal.fkip.unila.ac.id/index.php/aksara

\section{Pemahaman antar budaya}

Pemahaman antarbudaya melibatkan perkembangan pengetahuan, kesadaran dan pemahaman budaya dan bahasa seseorang, serta bahasa dari dunia yang berbahasa Indonesia. Studi tentang konteks dan topik pembelajaran, jenis teks dan konvensi tekstual dan sumber daya linguistik, akan memungkinkan pengembangan pemahaman antar budaya yang meningkatkan kemampuan untuk berkomunikasi, berinteraksi dan bernegosiasi di dalam dan di antara bahasa dan budaya. Dalam hal ini, diharapkan para siswa dapat mengembangkan kesadaran budaya dan isu-isu budaya yang mengatur cara berbicara dan berperilaku dalam masyarakat yang berbahasa Indonesia, dan mulai menerapkannya agar dapat berkomunikasi secara efektif.

\section{Pembelajaran bahasa dan strategi komunikasi}

Strategi pembelajaran dan komunikasi bahasa adalah proses, teknik, dan keterampilan yang relevan untuk mendukung pembelajaran dan akuisisi bahasa, membuat makna dari teks, menghasilkan teks, serta terlibat dalam interaksi lisan.

\section{KESIMPULAN}

Hasil penelitian ini menyatakan adanya kebutuhan pengembangan materi audio yang autentik. Materi audio yang dikembangkan harus disesuaikan dengan kurikulum yang berlaku pada pembelajaran bahasa Indonesia kelas XII. Materi yang dikembangkan dapat mencakup topik mengenai teks dan genre, media dan hiburan, globalisasi dan media, masalah remaja, isu-isu sosial, dan hubungan Australia / Indonesia. Hasil penelitian awal ini dapat menjadi suatu panduan dan dasar untuk melakukan prosedur penelitian pengembangan pada tahap selanjutnya.

\section{DAFTAR PUSTAKA}

Adam, dkk. (2010). The role of authentic materials in foreign language teaching. Bulletin UASVM Horticulture, 67(2),

Belaid, A., dan Murray, Liam. (2015). Using authentic materials in the foreign language classrooms: Teacher attitudes and perceptions in Libyan universities. International Journal of Learning and Development, 5(3).

Gilmore, Alex. (2007). Authentic materials and authenticity in foreign language learning. Language Teaching.

Jacobson, E., Degener, S., \& Purcell-Gates, V. (2003). Creating authentic materials and activities for the adult literacy classroom: A handbook for practitioners. Boston: World Education.

Kohler, Michelle dan Mahnken, Phillip. (2010). The current state of Indonesian language education in Australian schools. Victoria: Education Services Australia Ltd. 
AKSARA Jurnal Bahasa dan Sastra

Vol. 20, No. 1, Hal. 1 - 9, April 2019

http://jurnal.fkip.unila.ac.id/index.php/aksara

Renukadevi, D. (2014). The role of listening in language acquisition: The challenges \& strategies in teaching listening. International Journal of Education and Information Studies, 4 (1).

School Curriculum and Standards Authority. (2017). Indonesian second language atar course: Year 12 syllabus.

Slaughter, Yvette. (2007). The rise and fall of Indonesian in Australian schools: Implications for language policy and planning. Asian Studies Review, 31.

Smaldino, S., Lowther, D., dan Russel, J. (2011). Instructional technology and media for learning. Boston: Pearson Education Inc.

Suyitno, Imam. (2017). "Teaching materials and techniques needed by foreign students in learning bahasa Indonesia". ISLLAC Journal of Intensive Studies on Language, Literature, Art, and Culture, 1 (1).

Yıldırım, S., dan Yıldırım, Ö. (2016). The importance of listening in language learning and listening comprehension problems experienced by language learners: A literature review. Abant İzzet Baysal Üniversitesi Eğitim Fakültesi Dergisi, 16 (4), 2094-2110. 